\title{
Sublimation Enthalpies of Substituted Pyridine $\boldsymbol{N}$-Oxides
}

\author{
N. V. Belova ${ }^{a}$, N. I. Giricheva ${ }^{b}$, Yu. A. Zhabanov ${ }^{a}$, V. P. Andreev ${ }^{c}$, and G. V. Girichev ${ }^{a} *$ \\ ${ }^{a}$ Ivanovo State University of Chemistry and Technology, Ivanovo, 153460 Russia \\ ${ }^{b}$ Ivanovo State University, Ivanovo, 153025 Russia \\ ${ }^{c}$ Petrozavodsk State University, Petrozavodsk, 185910 Russia \\ *e-mail: g.v.girichev@mail.ru
}

Received June 29, 2021; revised July 22, 2021; accepted July 26, 2021

\begin{abstract}
The enthalpies of sublimation of five substituted pyridine $N$-oxides were determined by the Knudsen effusion method with mass spectrometric control of the vapor composition within the framework of the second law of thermodynamics. The sublimation enthalpy of mono-substituted compounds 4-X-PyO depends on the nature of the substituent $\mathrm{X}$ and increases in the order $\mathrm{CH}_{3} \rightarrow \mathrm{NO}_{2} \rightarrow \mathrm{OCH}_{3}$. A difference is noted in the nature of dissociative ionization of disubstituted derivatives $2-\mathrm{CH}_{3}-4-\mathrm{NO}_{2} \mathrm{PyO}$ and 3- $\mathrm{CH}_{3}-4-\mathrm{NO}_{2} \mathrm{PyO}$. The relationship between the packing of molecules in crystals and the $\Delta H_{\text {subl }}^{\circ}$ values is considered.
\end{abstract}

Keywords: pyridine $N$-oxide, Knudsen method, mass spectrometry, sublimation enthalpy

DOI: $10.1134 / \mathrm{S} 1070363221100029$

Many heterocyclic $N$-oxides exhibit high biochemical activity [1]. Among the $N$-oxides there are compounds with carcinogenic, mutagenic, herbicidal, fungicidal, insecticidal, bactericidal, analgesic, anticonvulsant, growth-regulating, and apoptogenic activities [2,3]. The unique biological activity of $N$-oxides makes it possible to use them as inhibitors in the fight against various viruses, including HIV [4, 5], and against strains of the SARS virus [6], and also for the regulation of the $\mathrm{Na}$, K-ATPhase activity [7]. Medicines are being developed on the basis of heterocyclic $\mathrm{N}$-oxides. However, the data obtained are insufficient to reveal regularities in the change in the biological activity of $\mathrm{N}$-oxides upon the introduction of substituents.

$\mathrm{N}$-Oxides are convenient intermediates in nucleophilic substitution reactions in organic synthesis [3, 8-10]. There is information about the use of some $\mathrm{N}$-oxides in photonics in order to develop new materials for nonlinear optics [11].

In contrast to unoxidized analogs, $\mathrm{N}$-oxides have a number of unique properties caused, among other things, by the accessibility of the reaction center and its high nucleophilic reactivity (supernucleophilicity).
According to numerous studies, the biochemical activity of heterocyclic $\mathrm{N}$-oxides is directly related to complex formation in living organisms [12-14]. Complexes of $N$-oxides with $d$-metals have magnetic properties $[15,16]$. In addition, $N$-oxides are promising reagents for the extraction of metal ions.

The specificity of the $\mathrm{N}$-oxides properties is caused by the peculiarities of the $\mathrm{N} \rightarrow \mathrm{O}$ functional group, which can act both as an acceptor and as an electron donor. This depends not only on the structure of the $N$-oxide itself, but also on the compound that reacts with it. The properties of the $\mathrm{N} \rightarrow \mathrm{O}$ bond can vary depending on the various substituents on the ring. Changing substituents creates wide opportunities for chemical modifications of $\mathrm{N}$-oxides and makes it possible to affect their properties as complexing agents.

Our quantum-chemical study of a number of $\mathrm{N}$-oxides [17] made it possible to detect the effect of donor and acceptor substituents on some characteristics of the $\mathrm{N} \rightarrow \mathrm{O}$ bond, whereas the electron diffraction study of $4-\mathrm{CH}_{3} \mathrm{PyO}$ 1 [18] and 4- $\mathrm{NO}_{2} \mathrm{PyO} 2$ [19] molecules helped to refine their structure (Fig. 1). 


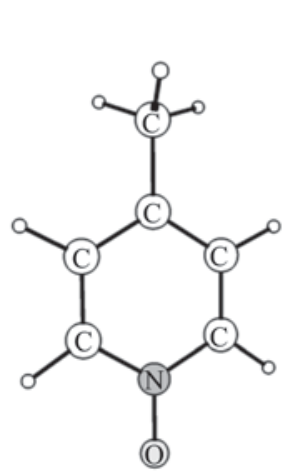

1

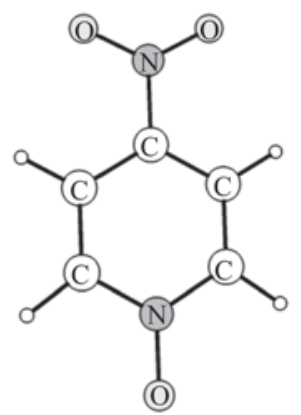

2

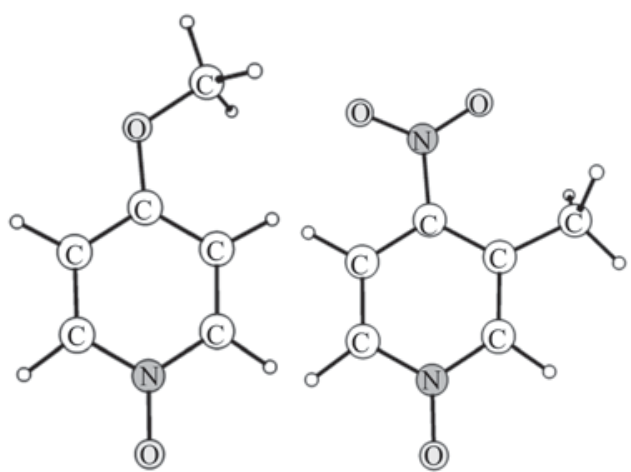

3
4

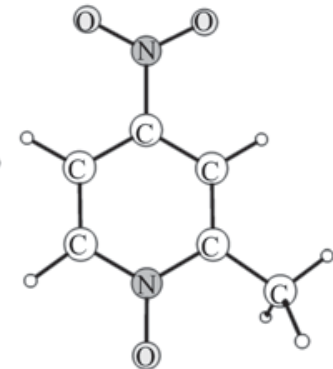

5

Fig. 1. Molecular structure of studied $\mathrm{N}$-oxides 1-5.

For a series of substituted pyridine $N$-oxides 1-5, we have studied the vaporization and composition of the gas phase by the Knudsen effusion method with mass spectrometric control of the vapor composition, the fragmentation of molecules upon their ionization by electrons, and the effect of the nature, position, and number of substituents in pyridine $\mathrm{N}$-oxides on the fragmentation. There are only fragmentary, often contradictory, data on the sublimation enthalpy of some para-substituted pyridine $N$-oxides [20-23]. The $\Delta H_{\text {subl }}^{\circ}$ values found for compound $\mathbf{2}$ in two different studies $[20,21]$ differ significantly. In [21], the microcalorimetric method of vacuum sublimation was used to determine the sublimation enthalpy, and in [20], the total vapor pressure was measured by the method of free evaporation in vacuum (Langmuir method). Most of the works on the study of the thermodynamics of vaporization is based on the measurement of the total vapor pressure. However, the composition of the gas phase is often complicated by the formation of oligomeric forms, the presence of volatile impurities, or the decomposition of the starting material. To reliably determine the thermodynamic characteristics of vaporization, it seems important to control the composition of the gas phase during the effusion experiment.

Table 1 shows the relative current intensities and stoichiometry of ions recorded in the mass spectra of compounds 1-5. The nature of the mass spectra points to the presence of molecular forms and the absence of impurities and oligomeric forms in the gas phase over the studied compounds under the experimental conditions. In all the mass spectra, the most intense is the molecular ion.
In the mass spectra of $\mathbf{1}, \mathbf{3}$, and $\mathbf{4}$ oxides, the ions caused by the detachment of the $\mathrm{CH}_{3}$ group have a high intensity. The mass spectra of oxides $\mathbf{2}$ and $\mathbf{4}$ contain ions associated with the elimination of the $\mathrm{O}$ atom from the $\mathrm{NO}_{2}$ group. The $\left[\mathrm{C}_{5} \mathrm{H}_{n} \mathrm{~N}\right]^{+}$ions are recorded in the mass spectra of four compounds, with the exception of 4- $\mathrm{NO}_{2} \mathrm{PyO} 2$, whereas the $\left[\mathrm{C}_{4} \mathrm{H}_{n}\right]^{+}$ion is present in each mass spectrum.

Comparison of the mass spectra of disubstituted pyridine oxides shows a difference in the directions of dissociative ionization of these molecules. The mass spectrum of oxide 4 contains signals of the $\left[\mathrm{C}_{5} \mathrm{H}_{3} \mathrm{NO}(\mathrm{NO})\right]^{+}$and $\left[\mathrm{C}_{5} \mathrm{H}_{3} \mathrm{NO}\right]^{+}$ions, $\mathrm{m} / z \mathrm{z} 123$ and 94, whereas the $\left[\mathrm{C}_{5} \mathrm{H}_{n} \mathrm{NO}\right]^{+}$ion, $\mathrm{m} / z 109$, is absent. The absence of the first two ions, as well as the $\left[\mathrm{CH}_{3}\right]^{+}$ion, from the mass spectrum of oxide $\mathbf{5}$ indicates that the removal of the methyl group from the ortho-position in relation to the $\mathrm{N} \rightarrow \mathrm{O}$ group is unlikely, in contrast to $p$-and $m$-methyl-substituted pyridine oxides. This is also evidenced by the presence of $\left[\mathrm{C}_{5} \mathrm{H}_{3} \mathrm{NO}\left(\mathrm{CH}_{3}\right)(\mathrm{NO})\right]^{+}$and $\left[\mathrm{C}_{5} \mathrm{H}_{3} \mathrm{NO}\left(\mathrm{CH}_{3}\right)\right]^{+}$ions with $\mathrm{N} \rightarrow \mathrm{O}$ and $\mathrm{CH}_{3}$ groups.

The presence of a peak corresponding to the $[\mathrm{HCN}]^{+}$ radical cation is characteristic of $N$-heteroaromatic compounds with the exception of $o$-methylpyridine oxide. Consequently, this type of substitution gives a special direction to the fragmentation of the molecule under the electron impact action.

The form of our mass spectra of pyridine $\mathrm{N}$-oxides with various substituents is consistent with the form of the mass spectra of saturated vapors of these compounds [22]. The differences in the relative intensities of the ions seem to be associated with different experimental conditions. 
Table 1. Ion intensities in mass spectra of $N$-oxides $\mathbf{1}-\mathbf{5}$

\begin{tabular}{|c|c|c|c|c|c|c|}
\hline \multirow{2}{*}{$\operatorname{Ion}^{\mathrm{a}}$} & \multirow{2}{*}{$m / z$} & \multicolumn{5}{|c|}{$I_{\text {rel }}, \%$} \\
\hline & & 1 & 2 & 3 & 4 & 5 \\
\hline$\left[\mathrm{C}_{5} \mathrm{H}_{3} \mathrm{NOCH}_{3} \mathrm{NO}_{2}\right]^{+}$ & 154 & & & & $100[M]^{+}$ & $100[M]^{+}$ \\
\hline$\left[\mathrm{C}_{5} \mathrm{H}_{4} \mathrm{NO}\left(\mathrm{NO}_{2}\right)\right]^{+}$ & 140 & & $100[M]^{+}$ & & & \\
\hline$\left[\mathrm{C}_{5} \mathrm{H}_{3} \mathrm{NO}\left(\mathrm{NO}_{2}\right)\right]^{+}$ & 139 & & & & 50 & \\
\hline$\left[\mathrm{C}_{5} \mathrm{H}_{3} \mathrm{NO}\left(\mathrm{CH}_{3}\right)(\mathrm{NO})\right]^{+}$ & 138 & & & & & 40 \\
\hline$\left[\mathrm{C}_{5} \mathrm{H}_{4} \mathrm{NO}\left(\mathrm{OCH}_{3}\right)\right]^{+}$ & 125 & & & $100[M]^{+}$ & & \\
\hline$\left[\mathrm{C}_{5} \mathrm{H}_{4} \mathrm{NO}(\mathrm{NO})\right]^{+}$ & 124 & & 19 & & & \\
\hline$\left[\mathrm{C}_{5} \mathrm{H}_{3} \mathrm{NO}(\mathrm{NO})\right]^{+}$ & 123 & & & & 43 & - \\
\hline$\left[\mathrm{C}_{5} \mathrm{H}_{4} \mathrm{NO}\left(\mathrm{CH}_{3}\right)\right]^{+}$ & 110 & $100[M]^{+}$ & & & & \\
\hline$\left[\mathrm{C}_{5} \mathrm{H}_{4} \mathrm{NO}(\mathrm{O})\right]^{+}$ & 110 & - & 21 & 43 & - & - \\
\hline$\left[\mathrm{C}_{5} \mathrm{H}_{3} \mathrm{NO}\left(\mathrm{CH}_{3}\right)\right]^{+}$ & 109 & & - & - & - & 10 \\
\hline$\left[\mathrm{C}_{5} \mathrm{H}_{n} \mathrm{NO}\right]^{+}$ & 94 & 33 & 25 & 20 & 13 & - \\
\hline$\left[\mathrm{C}_{5} \mathrm{H}_{n} \mathrm{~N}\right]^{+}$ & 78 & 36 & - & 28 & 12 & 12 \\
\hline$\left[\mathrm{C}_{4} \mathrm{H}_{n} \mathrm{~N}\right]^{+}$ & 66 & 12 & - & 20 & - & - \\
\hline$\left[\mathrm{C}_{5} \mathrm{H}_{n}\right]^{+}$ & 63 & - & 15 & - & - & 15 \\
\hline$\left[\mathrm{C}_{4} \mathrm{H}_{n}\right]^{+\cdot}$ & 51 & 38 & 11 & 21 & 10 & 6 \\
\hline$\left[\mathrm{C}_{3} \mathrm{H}_{n}\right]^{+}$ & 39 & 32 & 45 & - & 10 & 12 \\
\hline$[\mathrm{HCN}]^{+\cdot}$ & 27 & 29 & 35 & 20 & 9 & - \\
\hline$\left[\mathrm{CH}_{3}\right]^{+}$ & 15 & 30 & - & 17 & 8 & - \\
\hline
\end{tabular}

${ }^{a}$ A group of ions differing in the number of hydrogen atoms (the intensity of the main ion included in the group is given).

The shape of the mass spectra of pyridine oxides 1 and $\mathbf{2}$ corresponds to the shape of the mass spectra recorded during synchronous electronographic/mass spectrometric (EG/MS) studies [18, 19], despite the fact that the vapor temperature of the studied compounds in EG/MS experiments exceeded the temperature range of our research by $20-50^{\circ} \mathrm{C}$. This allows us to conclude that pyridine oxides $\mathbf{1}$ and $\mathbf{2}$ are thermally stable over a wider temperature range.

For the currents of molecular ions in the mass spectra of each of the studied compounds, the $\ln (I T)=$ $f(1000 / T)$ dependences were plotted (Fig. 2). Each graph is a collection of points obtained with a sequential increase and decrease in temperature. It can be stated that the points on these dependences correspond to near-equilibrium states, since the hysteresis phenomena with increasing/decreasing temperature are very weakly expressed. In all cases, the $\ln (I T)=f(1000 / T)$ functions are well approximated by linear dependences, which is typical for vaporization occurring in a narrow temperature range without changing the condensed phase aggregate state. Since in all cases the maximum vapor temperature did not exceed the melting temperature of the compounds, it can be concluded that the sublimation corresponds to the vaporization.

The sublimation enthalpies were calculated by the linear regression method on the basis of ClausiusClapeyron equation within the framework of the II law of thermodynamics. The measurements were carried out in the temperature range for which the approximation $\Delta C_{\mathrm{p}}=0$ is permissible. The sublimation enthalpies are given in Table 2 together with the $\Delta H_{\text {subl }}^{\circ}$ values obtained by other methods.

The sublimation enthalpies of pyridine oxides 1 $[20,23]$ and $\mathbf{2}[20,21]$ determined by different authors, differ significantly from each other. Our results, obtained with the control of the gas phase composition, coincide within the experimental error with the results of [20], but noticeably differ from the results of [21] and [23].

The $\Delta H_{\text {subl }}^{\circ}$ values for pyridine oxides $\mathbf{3}$ and $\mathbf{5}$ were obtained for the first time. Despite the different nature of the substituents in the pyridine ring, the obtained values of the sublimation enthalpy are quite close to each other. Table 2 shows that the value of $\Delta H_{\text {subl }}^{\circ}$ for monosubstituted compounds 4-X-PyO depends on 

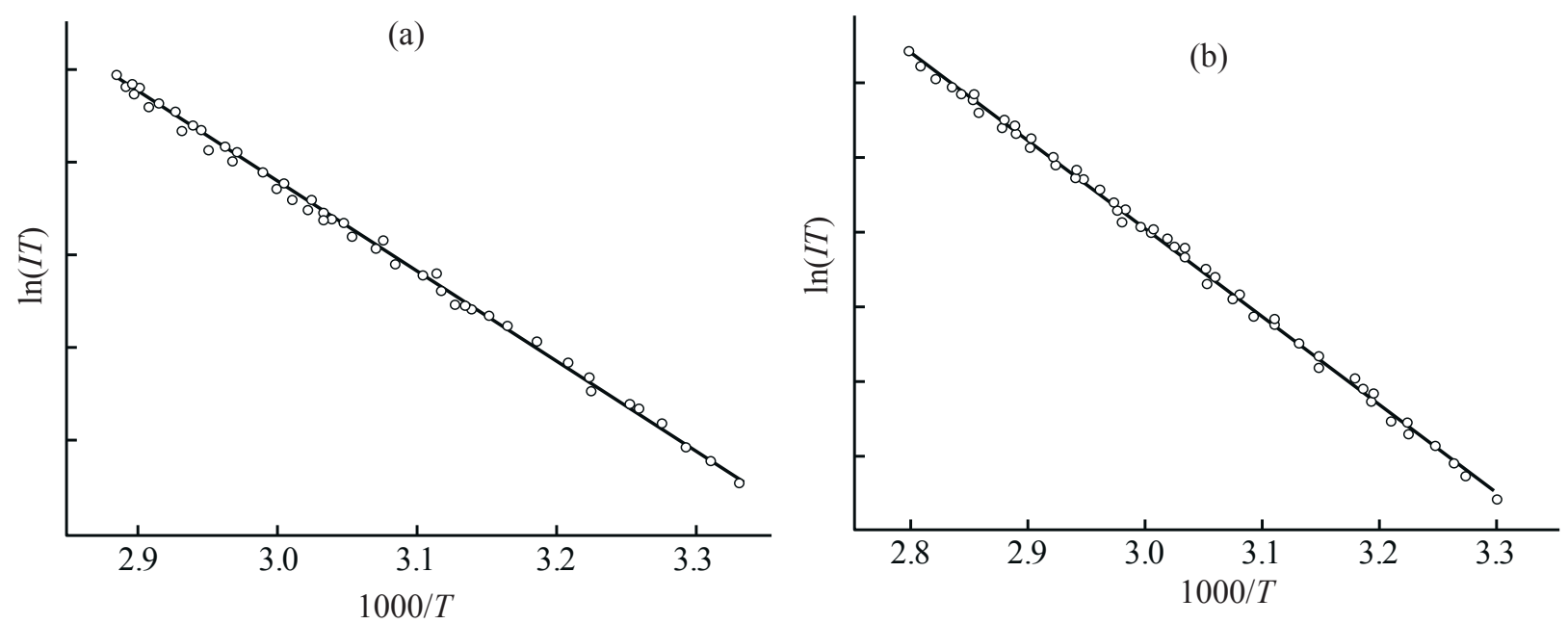

Fig. 2. Temperature dependences $\ln (I T)=f(1000 / T)$ of molecular ions currents in the mass spectra of molecules of $N$-oxides 1 and $\mathbf{5}$ of pyridine series used to determine the sublimation enthalpies (data recording modes are given in parentheses): (a) $4-\mathrm{CH}_{3} \mathrm{PyO} \mathbf{1}$ (heating-cooling- heating); (b) 2- $\mathrm{CH}_{3}-4-\mathrm{NO}_{2} \mathrm{PyO} 5$ (cooling-heating-cooling).

the nature of the substituent $\mathrm{X}$ in the para-position, increasing in the series $\mathrm{CH}_{3} \rightarrow \mathrm{NO}_{2} \rightarrow \mathrm{OCH}_{3}$, and for oxide 1 it practically coincides with the analogous value for unsubstituted pyridine oxide PyO (81.9(15) [24] and 79.3(10) $\mathrm{kJ} / \mathrm{mol}[25])$.

Our attempts to find a relationship between electronic characteristics of the substituents, dipole moments of individual molecules, and the $\Delta H_{\text {subl }}^{\circ}$ values were unsuccessful. We considered the crystal structure for four of five compounds [26-31], for which information is available in the Cambridge Structural Database [32].

Crystal of oxide 1 consists of two types of structural units, in which two molecules are oriented to each other by $\mathrm{CH}_{3}(\mathrm{H} \cdots \mathrm{H} 3.1 \AA)$ or $\mathrm{N} \rightarrow \mathrm{O}(\mathrm{O} \cdots \mathrm{O} 4.7 \AA)$ groups. The pyridine fragments in these units are located in mutually perpendicular planes [27]. Such a crystalline packing is not dense, and this facilitates the sublimation of compound $\mathbf{1}$.

Crystals of compounds $\mathbf{2}[26,28]$ and $\mathbf{5}$ [31] consist of flat layers with interlayer distances of 3.06 and $3.12 \AA$, respectively. In a layer, each molecule of the both compounds is surrounded by six neighboring molecules and has eight closest contacts $(2.2<r<2.8 \AA)$ $\mathrm{N} \rightarrow \mathrm{O} \cdots \mathrm{H}-\mathrm{C}$ and $\mathrm{NO}_{2} \cdots \mathrm{H}-\mathrm{C}$. The number of short contacts (up to $2.4 \AA$ ) in the crystal of compound $\mathbf{5}$ is greater than in the crystal of compound $\mathbf{2}$, which is reflected in the $\Delta H_{\text {subl }}^{\circ}$ values of these oxides.

Table 2. Sublimation enthalpies of $N$-oxides PyO and 1-5

\begin{tabular}{|c|c|c|}
\hline \multirow{2}{*}{ Oxide } & \multicolumn{2}{|c|}{$\Delta H_{\mathrm{subl}}^{\circ}, \mathrm{kJ} / \mathrm{mol}$} \\
\hline & this work & references \\
\hline \multirow[t]{2}{*}{$\mathrm{PyO}$} & - & $81.9(15)[24]$ \\
\hline & & $79.3(10)[25]$ \\
\hline \multirow[t]{2}{*}{1} & $79.6(16)$ at $300-347 \mathrm{~K}$ & $79.1(1.3)$ at $316-341 \mathrm{~K}[20]$ \\
\hline & & $85.3(26)$ at $345-392 \mathrm{~K}[23]$ \\
\hline \multirow[t]{2}{*}{2} & $87.3(13)$ at $325-380 \mathrm{~K}$ & $89.1(2.5)$ at $311-335 \mathrm{~K}$ [20] \\
\hline & & $108.9(3)$ at $298 \mathrm{~K}[21]$ \\
\hline 3 & $100.0(12)$ at $315-362 \mathrm{~K}$ & - \\
\hline 4 & $104.6(20)$ at $310-358 \mathrm{~K}$ & $106.7(20)$ at $345-392 \mathrm{~K}$ [23] \\
\hline 5 & $98.2(16)$ at $303-358 \mathrm{~K}$ & - \\
\hline
\end{tabular}


The more ordered structure of oxide $\mathbf{2}$ in comparison with oxide $\mathbf{1}$ is probably responsible for the higher value of $\Delta H_{\text {subl }}^{\circ}$ of compound 2 (Table 2).

Comparison of the crystal packings of two disubstituted pyridine oxides reveals their fundamental difference. The crystal of oxide 5 [31] consists of flat layers, whereas the crystal of compound $\mathbf{4}$ consists of chains of molecules, between which there are short contacts $\mathrm{NO}_{2} \cdots \mathrm{H}-\mathrm{C}$ and $\mathrm{N} \rightarrow \mathrm{O} \cdots \mathrm{H}_{3} \mathrm{C}$, and also similar contacts between the chains [29].

The somewhat larger $\Delta H_{\text {subl }}^{\circ}$ of compound 4 as compared to oxide $\mathbf{5}$ is explained by the different number of short contacts (ten versus eight, respectively).

Thus, we have investigated the sublimation of five substituted pyridine $\mathrm{N}$-oxides: $4-\mathrm{CH}_{3} \mathrm{PyO} 1,4-\mathrm{NO}_{2} \mathrm{PyO}$ 2, 4- $\mathrm{CH}_{3} \mathrm{OPyO} 3,3-\mathrm{CH}_{3}-4-\mathrm{NO}_{2} \mathrm{PyO} 4$, and 2- $\mathrm{CH}_{3}-4-$ $\mathrm{NO}_{2} \mathrm{PyO} 5$ using the Knudsen effusion method with mass spectrometric control of the gas phase composition. For oxides $\mathbf{3}$ and $\mathbf{5}$, the $\Delta H_{\text {subl }}^{\circ}$ values were determined for the first time. For compounds $\mathbf{1}$ and $\mathbf{2}$, the existing contradiction in the $\Delta H_{\text {subl }}^{\circ}$ values is eliminated. The $\Delta H_{\text {subl }}^{\circ}$ value for monosubstituted oxides 4-X-PyO depends on the nature of the substituent $\mathrm{X}$ in the para-position and increases in the series $\mathrm{CH}_{3} \rightarrow \mathrm{NO}_{2} \rightarrow \mathrm{OCH}_{3}$.

\section{EXPERIMENTAL}

The $\mathrm{N}$-oxides of 4-nitropyridine, 2-methyl-4-nitropyridine, 3-methyl-4-nitropyridine, 4-methylpyridine, and 4-methoxypyridine were synthesized and purified according to the described methods $[33,34]$. Chromatographic analysis, the absence of ions in the mass spectra that could be attributed to volatile impurities, and also the completeness of the preparations burnout at the end of the effusion experiment point to their high purity. The effusion experiment was carried out on a serial MI-1201 mass spectrometer, re-equipped for thermodynamic studies [35].

When studying saturated vapors over the substances under study, an effusion cell made of molybdenum was used, the ratio of the evaporation area/effusion hole area was 1000 . The ionizing voltage in the ion source was $30 \mathrm{~V}$. The temperature of the effusion cell was measured using a WRe-5/20 tungsten-rhenium thermocouple calibrated by the tin melting point. Mass spectra of the studied vapors were recorded in the temperature range given in Table. 2.

\section{AUTHOR INFORMATION}

N.V. Belova, ORCID: https://orcid.org/0000-0002-58466896

N.I. Giricheva, ORCID: https://orcid.org/0000-0001-70640693

Yu.A. Zhabanov, ORCID: https://orcid.org/0000-00018249-5534

V.P. Andreev, ORCID: https://orcid.org/0000-0001-7584$584 \mathrm{X}$

G.V. Girichev, ORCID: https://orcid.org/0000-0003-02643408

\section{FUNDING}

This work was supported by the Russian science foundation (grant no. 20-13-00359).

\section{CONFLICT OF INTEREST}

No conflict of interest was declared by the authors.

\section{REFERENCES}

1. Tae-Kyu, Ha, Theor. Chem. Acc., 1977, vol. 43, p. 337. https://doi.org/10.1007/BF00548689

2. Andreev, V.P., Korvacheva, E.G., and Nizhnik, Ya.P., Pharm. Chem. J., 2006, vol. 40, no. 7, p. 347. https://doi.org/10.1007/s11094-006-0124-5

3. Fukuhara, K., Hakura, A., Sera, N., Tokiwa, H., and Miyata, N., Chem. Res. Toxicol., 1992, vol. 5, no. 2, p. 149. https://doi.org/10.1021/tx00026a001

4. Albini, A. and Pietra, S., Heterocyclic N-Oxides, Boca Raton: CRC, 1991.

5. Balzarini, J., Stevens, M., de Clercq, E., Schols, D., and Pannecouque, C., J. Antimicrob. Chemother., 2005, vol. 55 , no. 2 , p. 135 . https://doi.org/10.1093/jac/dkh530

6. Balzarini, J., Stevensand, M.,and Andrei, G., Helv. Chim. Acta, 2002, vol. 85, p. 2961. https://doi.org/10.1002/1522-2675(200209)85: 9<2961::AID-HLCA2961>3.0.CO;2-R

7. Balzarini, J., Keyaerts, E., Vijgen, L., Fandermeer, F., Stevens, M., De Clercq, E., Egberick, H., and van Ranst, M., J. Antimicrob. Chemother., 2006, vol. 57 , no. 3, p. 472. https://doi.org/10.1093/jac/dki481

8. Andersson, H., Wang, X., Björklund, M., Olsson, R., and Almqvist, F., Tetrahedron Lett., 2007, vol. 48, no. 39 , p. 6941. 
https://doi.org/10.1016/j.tetlet.2007.07.161

9. Kanyiva, K.S. and Nakao, Y.T.H., Angew. Chem. Int. Ed., 2007, vol. 46, no. 46, p. 8872.

https://doi.org/10.1002/anie.200703758

10. Keith, J.M., J. Org. Chem., 2006, vol. 71, no. 25, p. 9540. https://doi.org/10.1021/jo061819j

11. Dalton, R.L., Harper, A.W., Ghosn, R., Steier, W.H., Ziari, M., Fetterman, H., Shi, Y., Mustacich, R.V., Jen, A.K.-Y., and Shea, K.J., Chem. Mater., 1995, vol. 7 , no. 6 , p. 1060 .

https://doi.org/10.1021/cm00054a006

12. Arata, H., Shimizu, M., and Takamiya, K., J. Biochem., 1992, vol. 112, no. 4, p. 470.

https://doi.org/10.1093/oxfordjournals.jbchem.a123923

13. Takekawa, K., Sugihara, K., Kitamura, S., and Tatsumi, K., Biochem. Mol. Biol. Int., 1997, vol. 42, no. 5, p. 977. https://doi.org/10.1080/15216549700203421

14. Takekawa, K., Kitamura, S., Sugihara, K., and Ohta, S., Xenobiotica, 2001, vol. 31, no. 1, p. 11. https://doi.org/10.1080/00498250010024997

15. Baran, P., Boča, R., Breza, M., Elias, H., Fuess, H., Jorík, V., Klement, R., and Svoboda, I., Polyhedron, 2002, vol. 21, no. 16, p. 1561.

https://doi.org/10.1016/S0277-5387(02)01020-3

16. Vrbová, M., Baran, P., Boča, R., Fuess, H., Svoboda, I., Linert, W., Schubert, U., and Wiede, P., Polyhedron, 2000, vol. 19, nos. 20-21, p. 2195.

https://doi.org/10.1016/S0277-5387(00)00553-2

17. Belova, N.V., Giricheva, N.I., and Fedorov, M.S., Struct. Chem., 2015, vol. 26, nos. 5-6, p. 1459. https://doi.org/10.1007/s11224-015-0621-9

18. Belova, N.V., Girichev, G.V., Kotova, V.E., Korolkova, K.A., and Trang, N.H., J. Mol. Struct., 2018, vol. 1156, p. 210. https://doi.org/10.1016/j.molstruc.2017.11.070

19. Belova, N.V., Pimenov, O.A., Kotova, V.E., and Girichev, G.V., J. Mol. Struct., 2020, vol. 1217, p. 128476. https://doi.org/10.1016/j.molstruc.2020.128476

20. Lebedev, V.P., Chironov, V.V., Kizin, A.N., Falyakhov, I.F., Saifullin, I.Sh., Klyuchnikov, O.R., Orlov, Yu.D., and Lebedev, Yu.A., Izv. Akad. Nauk., Ser. Khim., 1995, vol. 4, p. 660.

21. Acree, W.E., Tucker, S.A., Ribero da Silva, M.D.M.C., Matos, M.A.R., Goncales, J.M., Ribero da Silva, M.A.V., and Pilcher, G., J. Chem. Thermodyn., 1995, vol. 27, no. 4 , p. 391.

https://doi.org/10.1006/jcht.1995.0038

22. NIST Chemistry WebBook. webbook.nist.gov/chemistry.

23. Ribero da Silva, M.A.V., Agostinha, M., Matos, R., Claudia Vaz, M., Santos, L.M.N.B.F., Pilcher, G., Acree, W.E.Jr., and Powell, J.R., J. Chem. Thermodyn., 1998, vol. 30, p. 869.

https://doi.org/10.1006/jcht.1998.0353

24. da Silva, M.L.C.P., Chagas, A.P., and Airoldi, C., J. Chem. Soc. Dalton Trans., 1988, p. 2113.

https://doi.org/10.1039/DT9880002113

25. Shaofeng, L. and Pilcher, G., J. Chem. Thermodyn., 1988, vol. 20, no. 4, p. 463. https://doi.org/10.1016/0021-9614(88)90184-X

26. Wang, Y., Blessing, R.H., Ross, F.K., and Coppens, P., Acta Crystallogr. B, 1976, vol. 32, no. 2, p. 572. https://doi.org/10.1107/S0567740876003439

27. Morris, E.K., Cousson, A., Paulus, W., Z. Kristallogr. New Cryst. Struct., 1998, vol. 213, nos. 1-4, p. 80. https://doi.org/10.1524/ncrs.1998.213.14.80

28. Coppens, P. and Lehmann, M.S., Acta Crystallogr. $B, 1976$, vol. 32, p. 1777. https://doi.org/10.1107/S0567740876006389

29. Shiro, M., Yamakawa, M., and Kubota, T., Acta Crystallogr. $B, 1977$, vol. 33, p. 1549. https://doi.org/10.1107/S0567740877006475

30. Moreno-Fuquen, R., Cano, F., Martinez-Ripoll, M., Montaño, A., and Zukerman-Schpector, J., Acta Crystallogr. E, 2001, vol. 57, p. o712. https://doi.org/10.1107/S1600536801010790

31. Songxian, L., Shixiong, L., Wenshi, W., and Huaxue, J., Chin. J. Struct. Chem., 1987, vol. 6, p. 20.

32. Deposit no. NTPYRO11, ZZZVCO04, MNPYDO, FEXBUF. C Cambridge Structural Database System. https:// www.ccdc.cam.ac.uk.

33. Ochiai, E., J. Org. Chem., 1953, vol. 18, p. 534. https://doi.org/10.1021/jo01133a010

34. Ochiai, E., Aromatic Amines Oxides, Amsterdam: Elsevier, 1967.

35. Shlykov, S.A., Doctorate (Chem.) Dissertation, Ivanovo: Ivanovo State Chemical-Technological Inst., 2008. 